\title{
Nonlinear Stark effect observed for carbon monoxide chemisorbed on gold core/palladium shell nanoparticle film electrodes, using in situ surface-enhanced Raman spectroscopy
}

\author{
Pu Zhang a , Yi Wei a , Jun Cai a, Yan-Xia Chen a,*, Zhong-Qun Tian ${ }^{\mathrm{b}}$ \\ a Hefei National Laboratory for Physical Sciences at Microscale Department of Chemical Physics, University of Science and Technology of China, Hefei \\ 230026, Anhui, China \\ b State Key Laboratory of Physical Chemistry of Solid Surfaces, Department of Chemistry, College of Chemistry and Chemical Engineering, Xiamen \\ University, Xiamen, 361005, Fujian, China
}

\section{A R T I C L E I N F O}

\section{Article history:}

Received 14 March 2016

Accepted 14 April 2016

Published 5 July 2016

\section{Keywords:}

Carbon monoxide

Surface-enhanced Raman spectroscopy

Palladium

Density functional theory

Stark effect

\begin{abstract}
A B S T R A C T
The potential $(E)$-dependent vibrational behavior of a saturated $\mathrm{CO}$ adlayer on $\mathrm{Au}$-core $\mathrm{Pd}$-shell nanoparticle film electrodes was investigated over a wide potential range, in acidic, neutral, and basic solutions, using in situ surface-enhanced Raman spectroscopy (SERS). Over the whole of the examined potential region ( -1.5 to $0.55 \mathrm{~V}$ vs. NHE), the peak frequencies of both the $\mathrm{C}-\mathrm{O}_{\mathrm{M}}$ and the $\mathrm{Pd}-\mathrm{CO}_{\mathrm{M}}$ band (here, $\mathrm{M}$ denotes the multiply-bonded configuration) displayed three distinct linear regions: $\mathrm{d} \nu_{\text {с-ом }} / \mathrm{d} E$ decreased from $\sim 185-207$ (from -1.5 to $-1.2 \mathrm{~V}$ ) to $\sim 83-84 \mathrm{~cm}^{-1} / \mathrm{V}(-1.2$ to -0.15 $\mathrm{V}$ ), and then to $43 \mathrm{~cm}^{-1} / \mathrm{V}$ ( -0.2 to $0.55 \mathrm{~V}$ ); on the other hand, $\mathrm{d} \nu_{\text {Pd-com }} / \mathrm{d} E$ changed from $\sim-10$ to -8 $\mathrm{cm}^{-1} / \mathrm{V}$ (from -1.5 to $-1.2 \mathrm{~V}$ ) to $\sim-31$ to $-30 \mathrm{~cm}^{-1} / \mathrm{V}(-1.2$ to $-0.15 \mathrm{~V})$, and then to $-15 \mathrm{~cm}^{-1} / \mathrm{V}(-0.2$ to $0.55 \mathrm{~V}$ ). The simultaneously recorded cyclic voltammograms revealed that at $E<-1.2 \mathrm{~V}$, a hydrogen evolution reaction (HER) occurred. With the help of periodic density functional theory calculations using two different $(2 \times 2)-3 \mathrm{CO}$ slab models with $\operatorname{Pd}(111)$, the unusually high $\mathrm{d} v_{\mathrm{C}-\mathrm{OM}} / \mathrm{d} E$ and the small $\mathrm{d} \nu_{\text {Pd-COM }} / \mathrm{d} E$ in the HER region were explained as being due to the conversion of $\mathrm{CO}_{\text {ad }}$ from bridge to hollow sites, which was induced by the co-adsorbed hydrogen atoms formed from dissociated water at negative potentials.
\end{abstract}

(C) 2016, Dalian Institute of Chemical Physics, Chinese Academy of Sciences. Published by Elsevier B.V. All rights reserved.

\section{Introduction}

The potential-dependence of metal-adsorbate bonding at the electrochemical interface is an issue of basic importance in electrochemistry. One of the most extensively studied topics in this area is the vibrational Stark effect (a change in the vibrational frequency with respect to the applied electric field) of CO on platinum-group metal surfaces [1-4]. It is known that the observed Stark-tuning rates are sensitive to changes in the electrode materials [2,5], adsorbate coverage [5], binding geometry [6-8], and co-adsorbed species [6-9]; however, the mechanism responsible for the Stark effect remains a topic of debate [10]. One of the challenges commonly encountered is that it is impossible to find a system where the adsorbate coverage, adsorption sites, and the orientation of the system are constrained to a specific case as the potential is altered. Consequently, contributions to the band frequency changes from variations in the dipole-dipole coupling effects, and other

\footnotetext{
* Corresponding author. Tel/Fax: 86-551-63600035; E-mail: yachen@ustc.edu.cn

This work was supported by the National Natural Science Foundation of China (21473175), the National Instrumentation Program (2011YQ03012416) and the National Basic Reserarch Program of China (973 Program, 2015CB932301).

DOI: 10.1016/S1872-2067(15)61106-8 | http://www.sciencedirect.com/science/journal/18722067 | Chin. J. Catal., Vol. 37, No. 7, July 2016
} 
structure-dependent interactions, cannot be avoided [7,11].

Previous studies have investigated CO adsorption at a Pd electrode using electrochemical infrared adsorption spectroscopy (EC-IRAS) [8,12-15]. From the well-defined C-0 stretching vibration, it has been confirmed that $\mathrm{CO}$ can adsorb at atop $\left(\mathrm{CO}_{\mathrm{L}}\right)$, 2-fold bridge ( $\left.\mathrm{CO}_{\mathrm{B}}\right)$, and 3-fold hollow $\left(\mathrm{CO}_{\mathrm{H}}\right)$ sites. In this case, a linear Stark slope of the $\mathrm{C}-\mathrm{O}$ stretching vibration $\left(\mathrm{d} v_{\mathrm{c}-\mathrm{OM}} / \mathrm{d} E \approx 40 \pm 10 \mathrm{~cm}^{-1} / \mathrm{V}\right)$ is observed in acidic solutions $[8,15]$.

Although these studies have clarified the behavior in this system, difficulties remain because there is no direct correlation between the $\mathrm{CO}$ adsorption energy and the $\mathrm{C}-\mathrm{O}$ stretching frequency, because of the alteration of the spectral behavior of the $\mathrm{C}-\mathrm{O}$ stretching band by the strong dipole-dipole coupling effects between the nearby $\mathrm{CO}_{\mathrm{ad}}$ molecules. The dipole-dipole coupling effects for the metal-CO vibration are much weaker than those for the $\mathrm{C}-\mathrm{O}$ vibration [16]. Information on $\mathrm{Pd}-\mathrm{CO}$ stretching cannot be obtained in electrochemical environments using EC-IRAS, because of the limited transparency of the IR window (normally $>800 \mathrm{~cm}^{-1}$ ), and the strong absorption in the far-infrared region by water, which is typically used as the solvent in such studies. In contrast, surface-enhanced Raman spectroscopy (SERS) can be used to obtain vibrational information in a wide spectral window $\left(5-4000 \mathrm{~cm}^{-1}\right)$, and does not require the use of the spectral-difference method to remove solution-phase interferences. However, few electrochemical in-situ SERS studies have been carried out on CO adsorption on Pd substrates, because SERS studies on pure roughened Pd electrodes are typically limited by the poor surface sensitivity. Zou et al. [2] studied the Stark effects of CO adsorption on Pd film-coated $\mathrm{Au}$ electrodes by borrowing the strong SERS enhancement from the Au substrate, and found that the slope for the Pd-CO stretching vibration $\left(\mathrm{d} \nu_{\mathrm{Pd}-\mathrm{COM}} / \mathrm{d} E\right)$ was roughly linear $\left(\sim-10 \mathrm{~cm}^{-1} / \mathrm{V}\right)$. However, because of the limited range of potentials applied in the above studies, it is difficult to infer how the external electric field effect influenced the adsorption behavior for $\mathrm{CO}_{\mathrm{ad}}$ at the Pd electrodes.

Here, we report potential-dependent vibrational Stark behavior, based on surface-enhanced Raman measurements of a $\mathrm{CO}$ adlayer at an Au-core/Pd-shell nanoparticle film electrode in acidic, neutral, and basic aqueous media, in a broad potential region from -1.5 to $0.55 \mathrm{~V}$. The potential range accessible for SERS measurements is determined by the onset of $\mathrm{CO}_{\mathrm{ad}}$ oxidation and a strong hydrogen evolution reaction (HER); the potential range can be expanded by using different electrolytes. Our results revealed distinct Stark slopes in three different potential regions, with a pronounced increase in $\mathrm{d} v_{\mathrm{C}-\mathrm{o}} / \mathrm{d} E$, and a decrease in $\left|\mathrm{d} \nu_{\mathrm{Pd}-\mathrm{CO}} / \mathrm{d} E\right|$ (the absolute value of $\mathrm{d} \nu_{\mathrm{Pd}-\mathrm{Co}} / \mathrm{d} E$ ) at potentials where the HER reaction occurred. Such spectral behavior was preliminarily attributed to the $\mathrm{CO}_{\mathrm{ad}}$ site transition induced by the co-adsorbed hydrogen atoms involved in the HER, as confirmed using periodic density functional theory (DFT) calculations.

\section{Experimental and computational}

\subsection{Experimental set-up}

The design of the electrochemical flow cell used in the present SERS study has been described in detail elsewhere [17]. The electrolyte flowing through the cell could be switched between different electrolytic reservoirs, where the flow rate was controlled by changing the hydraulic pressure. In this experiment, the flow rate was $50 \mu \mathrm{L} / \mathrm{s}$. All measurements were performed at ambient temperature $\left(25 \pm 3{ }^{\circ} \mathrm{C}\right)$. A thin $\mathrm{Au}$ foil (thickness $50 \mu \mathrm{m}$ ) and a saturated calomel electrode (SCE) were used as the counter electrode (CE) and the reference electrode (RE), respectively. Here, all potentials are reported with respect to normal hydrogen electrode (NHE).

Electrochemical measurements were conducted using a CHI631B electrochemical workstation (CH Instruments, Shanghai, China). SERS measurements were carried out using a confocal microprobe Raman system (LabRam I from Dilor, France), using an air-cooled CCD and a He-Ne laser operating at $632.8 \mathrm{~nm}$. The laser power delivered at the sample (with beam diameter of ca. $2 \mu \mathrm{m}$ ) was approximately $5 \mathrm{~mW}$. The microscope attachment was based on an Olympus BX40 system, using a long working length $(8 \mathrm{~mm}) \times 50$ objective. A $1800 \mathrm{~g} / \mathrm{mm}$ grating was used, and the spectral resolution was $1 \mathrm{~cm}^{-1}$.

\subsection{Chemicals, and preparation of 55 nm Au@0.7 nm Pd nanoparticle film electrodes}

$\mathrm{PdCl}_{2}$ (99.9\%), $\mathrm{HAuCl}_{4}$ (AR), $\mathrm{HCl}$ (AR), sodium citrate (AR), ascorbic acid (AR), $\mathrm{Na}_{2} \mathrm{SO}_{4}(\mathrm{AR}), \mathrm{H}_{2} \mathrm{SO}_{4}$ (GR), and $\mathrm{NaOH}$ (GR) were purchased from Shanghai Reagent Corporation, China. Millipore Milli-Q Water $(18.2 \mathrm{M} \Omega / \mathrm{cm})$ was used throughout the study. Before SERS measurements, all of the electrolyte solutions were deaerated via continuous $\mathrm{N}_{2}$ (4N, Linde Gas China) purging. CO-saturated solutions were achieved by pre-bubbling the supporting electrolyte with pure CO (99.9\%, Linde Gas China) for $15 \mathrm{~min}$ in the electrolyte reservoir, and via continuous purging during the experiments.

55 nm Au@0.7 nm Pd nanoparticles were prepared by coating a thin layer $(0.7 \mathrm{~nm})$ of Pd over $55 \mathrm{~nm} \mathrm{Au}$ nanoparticles, following the procedure reported by Tian's group [18]. First, a $\mathrm{H}_{2} \mathrm{PdCl}_{4}(1.0 \mathrm{mmol} / \mathrm{L})$ aqueous solution was prepared by dissolving $88.6 \mathrm{mg}$ of $\mathrm{PdCl}_{2}$ in $11 \mathrm{~mL}$ of $0.1 \mathrm{~mol} / \mathrm{L} \mathrm{HCl}$ under heating and stirring, and diluting the resulting solution to a final volume of $500 \mathrm{~mL}$. Then, $30 \mathrm{~mL}$ of a sol containing $55 \mathrm{~nm}$ $\mathrm{Au}$ seeds was mixed with $0.8 \mathrm{ml} \mathrm{H}_{2} \mathrm{PdCl}_{4}$ (10 mmol/L)solution for several minutes, after synthesizing the $\mathrm{Au}$ nanoparticles with a diameter of ca. $55 \mathrm{~nm}$ by reducing $\mathrm{AuCl}_{4}^{-}$using sodium citrate. $0.4 \mathrm{ml}$ ascorbic acid (10 mmol/L) solution was slowly dropped into these mixtures under vigorous stirring, using a syringe controlled by a step motor. The mixtures were further stirred for approximately $20 \mathrm{~min}$, to ensure the complete reduction of the $\mathrm{H}_{2} \mathrm{PdCl}_{4}$. The $55 \mathrm{~nm} \mathrm{Au}$-core $0.7 \mathrm{~nm} \mathrm{Pd}$-shell (denoted as 55 nm Au@0.7 nm Pd or Au@Pd hereafter) sol was centrifuged three times, to remove excess reactants. The remaining sol $(5 \mu \mathrm{L})$ was then cast on a smooth Pd electrode (diameter ca. $1.5 \mathrm{~mm}$ ), and dried in a desiccator. This procedure was repeated three times, to ensure that the Pd electrode was completely covered with the Au@Pd nanoparticles. The nanoparticles displayed an ellipsoidal shape with a uniform 
size distribution, as demonstrated in scanning electron microscope (SEM) images (Fig. 1). Cyclic voltammograms (CVs) of the $55 \mathrm{~nm} \mathrm{Au@0.7} \mathrm{nm} \mathrm{Pd} \mathrm{nanoparticle-coated} \mathrm{Pd} \mathrm{electrode}$ measured in $0.5 \mathrm{~mol} / \mathrm{LH}_{2} \mathrm{SO}_{4}, 0.5 \mathrm{~mol} / \mathrm{L} \mathrm{Na}_{2} \mathrm{SO}_{4}$, and $0.5 \mathrm{~mol} / \mathrm{L}$ $\mathrm{NaOH}$ are shown in Fig. 2; the results agreed well with previous results reported in the literature, confirming that the nanoparticle film electrodes exhibited the electrochemical behavior of polycrystalline Pd [19-21]. We also checked the base CV using the upper potential limit of $1.5 \mathrm{~V}$ (not shown); the lack of a redox current peak for Au at higher potentials supported the conclusion that the Au core was well coated by the Pd shell.

\subsection{Experimental protocol}

Potential-dependent SERS experiments on the saturated $\mathrm{CO}_{\mathrm{ad}}$ layer at the $55 \mathrm{~nm} \mathrm{Au@0.7} \mathrm{nm} \mathrm{Pd/Pd} \mathrm{were} \mathrm{conducted}$ according to the following procedure. The electrode surface was first saturated with a $\mathrm{CO}_{\text {ad }}$ layer by flowing a $\mathrm{CO}$-saturated $0.5 \mathrm{~mol} / \mathrm{L} \mathrm{H}_{2} \mathrm{SO}_{4}$ solution through the cell for $15 \mathrm{~min}$, while the electrode potential was held at $0.05 \mathrm{~V}$. CVs were then measured over the potential range from -0.2 to $0.55 \mathrm{~V}$, at a scan rate of 1 $\mathrm{mV} / \mathrm{s}$, and the corresponding Raman spectra in the range from 1600 to $2250 \mathrm{~cm}^{-1}$ were recorded at a time resolution of $50 \mathrm{~s}$ per spectrum (50 $\mathrm{mV}$ per spectrum). The grating was switched to cover the region from 250 to $1050 \mathrm{~cm}^{-1}$, and the same potential program was repeated to record the spectral signal of the Pd-CO stretching vibration. All measurements were performed under continuous flowing with CO-saturated $\mathrm{H}_{2} \mathrm{SO}_{4}$. After scanning back to $-0.1 \mathrm{~V}$ in $0.5 \mathrm{~mol} / \mathrm{L} \mathrm{H}_{2} \mathrm{SO}_{4}$, the electro-

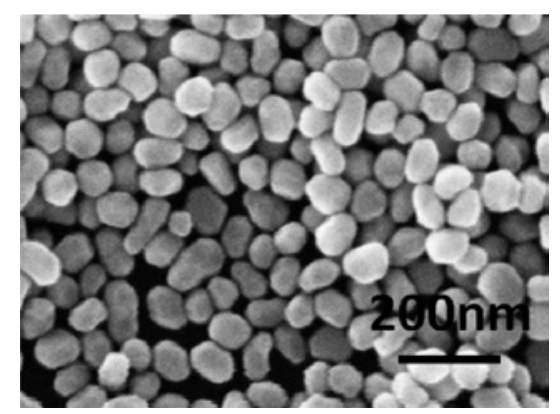

Fig. 1. SEM image of 55 nm Au@0.7 nm Pd core-shell nanoparticles.

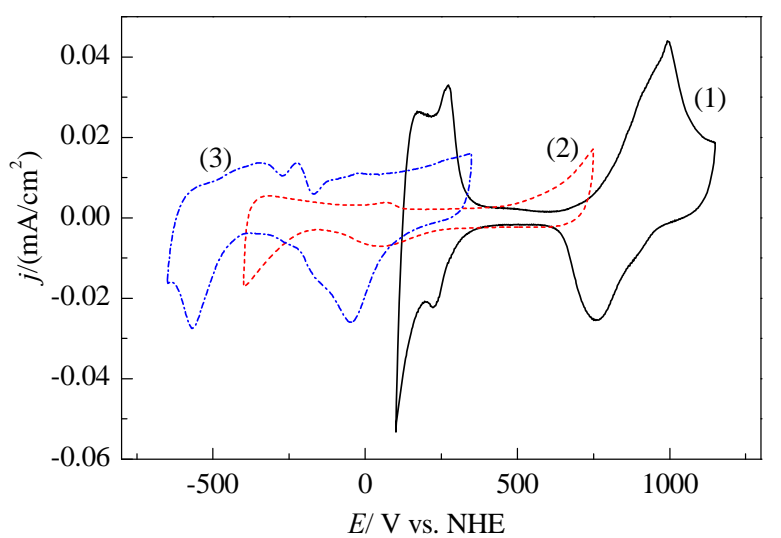

Fig. 2. Cyclic voltammograms of 55 nm Au@0.7 nm Pd/Pd in 0.5 mol/L $\mathrm{H}_{2} \mathrm{SO}_{4}\left(1, \mathrm{Na}_{2} \mathrm{SO}_{4}(2)\right.$ and $\mathrm{NaOH}(3)$ solution. Scan rate, $10 \mathrm{mV} / \mathrm{s}$ ). lyte solution was switched to CO-saturated $0.5 \mathrm{~mol} / \mathrm{L} \mathrm{Na}_{2} \mathrm{SO}_{4}$, while holding at $-0.1 \mathrm{~V}$ for ca. $5 \mathrm{~min}$. The area between the cell and the connecting tubes was carefully flushed with $0.5 \mathrm{~mol} / \mathrm{L}$ $\mathrm{Na}_{2} \mathrm{SO}_{4}$, to make sure that the solution exchange was complete. The electrode potential was then scanned negatively from -0.15 to $-1.5 \mathrm{~V}$, and then back again. Subsequently, the electrode potential was held at $-0.55 \mathrm{~V}$, and the electrolyte was switched to CO-saturated $0.5 \mathrm{~mol} / \mathrm{L} \mathrm{NaOH}$, and the $\mathrm{CV}$ from -0.4 to $-1.5 \mathrm{~V}$ was recorded. The Raman spectra of the $\mathrm{C}-\mathrm{O}$ and $\mathrm{Pd}-\mathrm{CO}$ stretching vibrations were also recorded in potential scans in neutral and basic solutions, similar to the case in the acidic solution.

\subsection{Computational details}

The first-principle calculations were performed using the plane-wave based Vienna ab initio simulation package (VASP) [22-24]. The exchange-correlation energy was calculated within the generalized gradient approximation (GGA) proposed by Perdew et al. [25]. The interaction between atomic cores and electrons was described using the projector augmented wave (PAW) approach [26], and the cutoff energy was set to $400 \mathrm{eV}$. Ionic iterations were performed until the forces on the ions were less than $0.003 \mathrm{eV} / \AA$. Brillouin zone integrations were performed on a $(5 \times 5 \times 1)$ grid of Monkhorst-Pack points [27]. Fractional occupancies were calculated using a first-order Methfessel-Paxton smearing function with a width of $0.2 \mathrm{eV}$ [28].

In the periodic DFT calculations, a slab model of $(2 \times 2)-3 \mathrm{CO}$ on $\mathrm{Pd}(111)$ was used to mimic the saturated $\mathrm{CO}$ adlayer at the $\mathrm{Pd} @ A u$ nanoparticle surface, because the coverage of $\mathrm{CO}_{\mathrm{ad}}$ on single crystalline $\mathrm{Pd}(111)$ and $\mathrm{Pd}$ nanoparticle surfaces is ca. $0.75 \mathrm{ML}$, as estimated from IRAS and SFG studies [29-31]. The $\mathrm{Pd}(111)$ surface was modeled by a periodic four-layer Pd slab with a $\mathrm{CO}$ adlayer adsorbed on one side of the slab. Each slab was separated from its periodic image in the z-direction by a vacuum space $(\sim 10 \AA)$, to avoid interaction between slabs. The two bottom layers of the slab were fixed at their bulk positions, while all upper layers have been fully relaxed in all calculations. The calculated equilibrium lattice constant for bulk Pd was $3.960 \AA$, which agreed well with an experimental value of 3.891 $\AA$ [32]. The calculations were made using two different $(2 \times$ 2)-3CO structures corresponding to the coverage of a 0.75 monolayer. The $(2 \times 2)-3 \mathrm{CO}$ structure had three adsorbed $\mathrm{CO}$ molecules in the unit cell. A structure with one atop and two bridge $\mathrm{CO}$ molecules $\left(\mathrm{CO}_{\mathrm{L}}+2 \mathrm{CO}_{\mathrm{B}}\right)$ was optimized and compared with another structure containing one atop, one (fcc), and one (hcp) hollow $\mathrm{CO}$ molecule $\left(\mathrm{CO}_{\mathrm{L}}+2 \mathrm{CO}\right)$ (Fig. 3). An electric field perpendicular to the slab was imposed using the method implemented in VASP [33]. Vibrational frequencies were calculated via diagonalization of the dynamical matrix. For the $\left(\mathrm{CO}_{\mathrm{L}}+2 \mathrm{CO}_{\mathrm{B}}\right)$ structure, the surface plane degrees of freedom of the $\mathrm{C}$ and $\mathrm{O}$ atoms were constrained to the ideal atop and bridge sites, because a full relaxation of all of the $\mathrm{C}$ and $\mathrm{O}$ atoms coordinates showed that this structure was not energetically stable. The two $(2 \times 2)-3 \mathrm{CO}$ slab models were used in our calculations for comparison. 


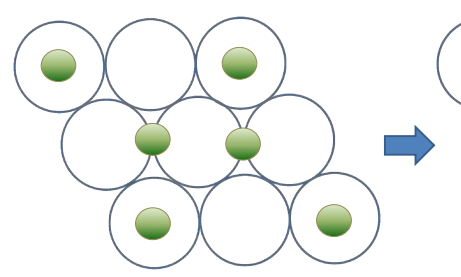

(a) $\mathrm{CO}_{\mathrm{L}}+2 \mathrm{CO}_{\mathrm{B}}$

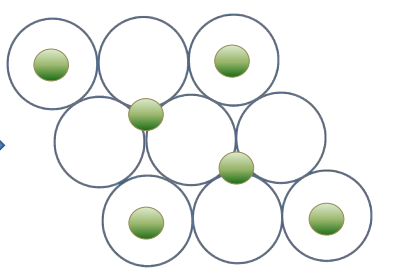

(b) $\mathrm{CO}_{\mathrm{L}}+2 \mathrm{CO}_{\mathrm{H}}$
Fig. 3. Two different Pd(111) $(2 \times 2)-3 \mathrm{CO}$ models used in the periodic DFT calculations. (a) $\mathrm{CO}_{\mathrm{L}}+2 \mathrm{CO}_{\mathrm{B}}$ : one atop- + two bridge-site $\mathrm{CO}$ molecules; (b) $\mathrm{CO}_{\mathrm{L}}+2 \mathrm{CO}_{\mathrm{H}}$ : one atop- + one fcc hollow- + one (hcp) hollow-site adsorbed $\mathrm{CO}$ molecules.

\section{Results and discussion}

\subsection{Potential-dependent SER spectral behavior of the saturated CO adlayer at a Au@Pd nanoparticle film electrode}

Fig. 4 shows selected SERS spectra of the Pd-CO and C-O stretching vibrations recorded during positive-direction potential sweeps from -0.2 to $0.55 \mathrm{~V}$ in $0.5 \mathrm{~mol} / \mathrm{L} \mathrm{H}_{2} \mathrm{SO}_{4}$, from -1.5 to $-0.15 \mathrm{~V}$ in $0.5 \mathrm{~mol} / \mathrm{L} \mathrm{Na}_{2} \mathrm{SO}_{4}$, and from -1.5 to $-0.4 \mathrm{~V}$ in 0.5 $\mathrm{mol} / \mathrm{L} \mathrm{NaOH}$. The bands at ca. 460 and $370 \mathrm{~cm}^{-1}$ were assigned to the $\mathrm{Pd}-\mathrm{C}$ stretching vibrations between the $\mathrm{Pd}$ surface and the linearly- $\left(\mathrm{CO}_{\mathrm{L}}\right)$ and multiply-bonded $\left(\mathrm{CO}_{\mathrm{M}}\right) \mathrm{CO}$ (the multiply-bonded $\mathrm{CO}$ might have included both bridge-bonded and hollow sites adsorbed $\mathrm{CO}$ whose peak frequencies were not far from each other), and the corresponding peaks centered at ca. 2070 and $1970 \mathrm{~cm}^{-1}$ were attributed to the C-O stretching vibrations of $\mathrm{CO}_{\mathrm{L}}$ and $\mathrm{CO}_{\mathrm{M}}$, respectively [2,15,29,34]. The lack of characteristic bands for $\mathrm{Au}-\mathrm{CO}$ and $\mathrm{C}-\mathrm{O}$ on top of $\mathrm{Au}$ further supported that the Au core was well coated by the Pd shell.

The corresponding changes in the band intensities and the peak frequencies were plotted as a function of electrode potential (Figs. 5, 6, and 7). Inspection of the $\mathrm{CO}_{\mathrm{M}}$ peak frequency-potential ( $\nu_{\mathrm{Pd}-\mathrm{COM}}-E$ and $\nu_{\text {сом }}-E$ ) curves in acidic and neutral solutions (Figs. 5(a) and 6(a)) showed that the Stark slopes could be divided into three linear potential regions: in CO-saturated $0.5 \mathrm{~mol} / \mathrm{L} \mathrm{Na}_{2} \mathrm{SO}_{4}, \mathrm{~d} \nu_{\text {Pd-Com }} / \mathrm{d} E$ and $\mathrm{d} \nu_{\text {C-OM }} / \mathrm{d} E$ were (1) ca. -8 and $207 \mathrm{~cm}^{-1} / \mathrm{V}$ from -1.5 to $-1.2 \mathrm{~V}$ and (2) -30 and $83 \mathrm{~cm}^{-1} / \mathrm{V}$ in the potential region from -1.2 to $-0.15 \mathrm{~V}$, and in CO-saturated $0.5 \mathrm{~mol} / \mathrm{L} \mathrm{H}_{2} \mathrm{SO}_{4}$, the slopes were -15 and 43 $\mathrm{cm}^{-1} / \mathrm{V}$ from -0.2 to $0.55 \mathrm{~V}$ (3), respectively. From the frequency-potential relationship in CO-saturated $0.5 \mathrm{~mol} / \mathrm{L} \mathrm{NaOH}$ (Fig. 7(a)), it was found that the Stark slopes for both $\mathrm{d} \nu_{\mathrm{Pd}-\mathrm{Co}} / \mathrm{d} E$ and $\mathrm{d} v_{\mathrm{c}-\mathrm{o}} / \mathrm{d} E$ strongly depended on the region of the applied electrode potentials. In the potential region from -1.5 to $-1.2 \mathrm{~V}$, the Stark slopes of $\mathrm{d} \nu_{\mathrm{Pd}-\mathrm{CO}} / \mathrm{d} E$ and $\mathrm{d} \nu_{\mathrm{C}-\mathrm{O}} / \mathrm{d} E$ were roughly constant, at -10 and $185 \mathrm{~cm}^{-1} / \mathrm{V}$, respectively; in the potential region from -1.2 to $-0.4 \mathrm{~V}$, the Stark rate $\mathrm{d} \nu_{\mathrm{Pd}-\mathrm{CO}} / \mathrm{d} E$ increased to $-31 \mathrm{~cm}^{-1} / \mathrm{V}$, while $\mathrm{d} v_{\mathrm{c}-\mathrm{o}} / \mathrm{d} E$ decreased to 84 $\mathrm{cm}^{-1} / \mathrm{V}$.

Furthermore, it was found that the band intensity of the $\mathrm{Pd}-\mathrm{CO}_{\mathrm{M}}$ and $\mathrm{C}-\mathrm{O}_{\mathrm{M}}$ stretching vibrations changed in opposite directions; i.e., the former decreased while the latter increased with increasing electrode potential during the posi-
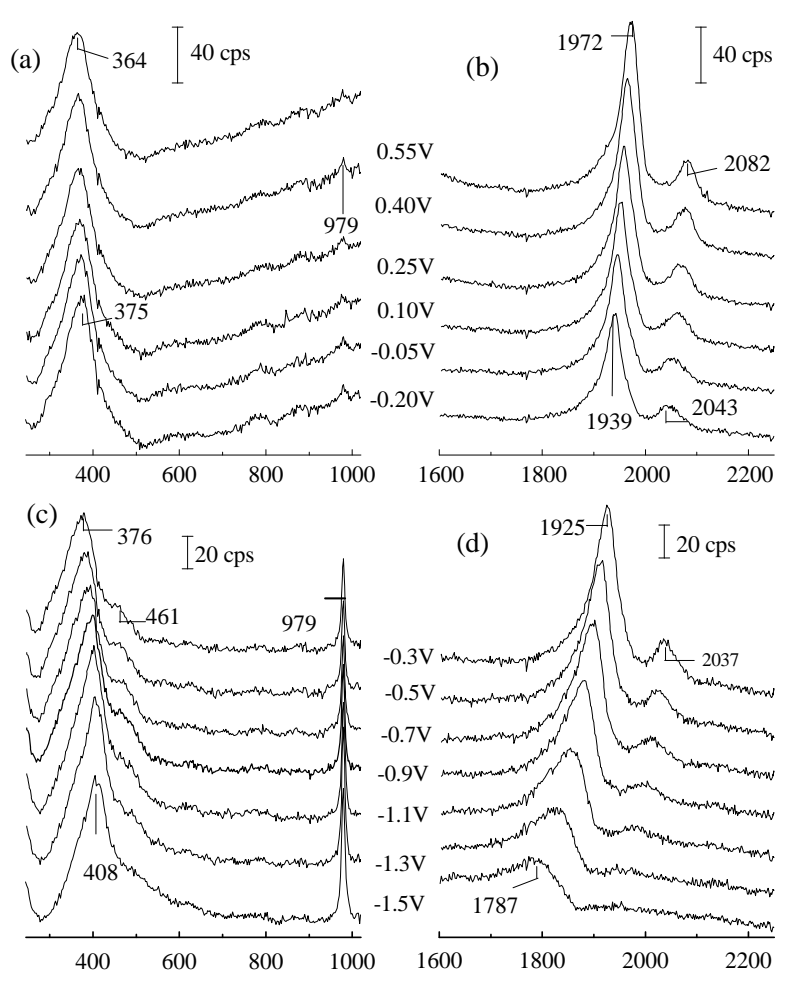

(e)
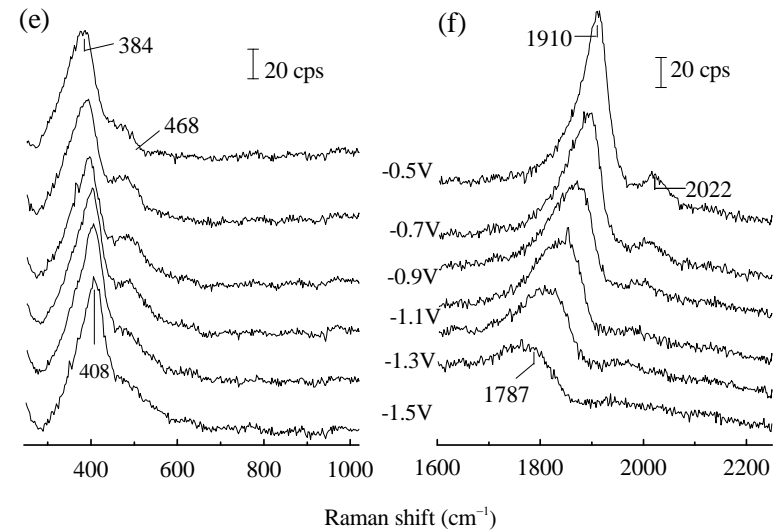

Fig. 4. Representative SER spectra of $\mathrm{Pd}-\mathrm{CO}(\mathrm{a}, \mathrm{c}, \mathrm{e})$ and $\mathrm{C}-\mathrm{O}$ (b, d, f) from adsorbed CO on 55 nm Au@0.7 nm Pd/Pd as a function of electrode potential in $\mathrm{CO}$ saturated $0.5 \mathrm{~mol} / \mathrm{L} \mathrm{H}_{2} \mathrm{SO}_{4}(\mathrm{a}, \mathrm{b}), 0.5 \mathrm{~mol} / \mathrm{L} \mathrm{Na}_{2} \mathrm{SO}_{4}$ (c, d) and $0.5 \mathrm{~mol} / \mathrm{L} \mathrm{NaOH}(\mathrm{e}, \mathrm{f})$. The spectra were taken with $50 \mathrm{~s}$ per spectrum.

tive-direction potential scan in the three solutions (Figs. 5(b), 6(b), and 7(b)). During the negative-direction scan (Figs. 5(c), $6(c)$, and $7(\mathrm{c})$ ), the band intensity of $\mathrm{C}-\mathrm{O}_{\mathrm{M}}$ increased with increasing electrode potential, while the band intensity for $\mathrm{Pd}-\mathrm{CO}_{\mathrm{M}}$ changed slightly; the experiments were carefully repeated, and these phenomena were found to be highly reproducible. A similar study was also performed using a grating with 1800 grooves; where the Raman spectra for both $\mathrm{Pd}-\mathrm{CO}$ and $\mathrm{C}-\mathrm{O}$ could be collected in the same spectra, the same trend was also observed. Such a trend was not observed in our recent study of the Pt/CO system [11]. These trends were not caused by changes in the $\mathrm{CO}_{\mathrm{ad}}$ coverage, but were probably induced by the different potential-dependent Raman scattering sections of the $\mathrm{Pd}-\mathrm{CO}_{\mathrm{M}}$ and $\mathrm{C}-\mathrm{O}_{\mathrm{m}}$ vibration modes. The reason for the opposite potential-dependent changes in the $\mathrm{Pd}-\mathrm{CO}$ and $\mathrm{C}-\mathrm{O}$ band 

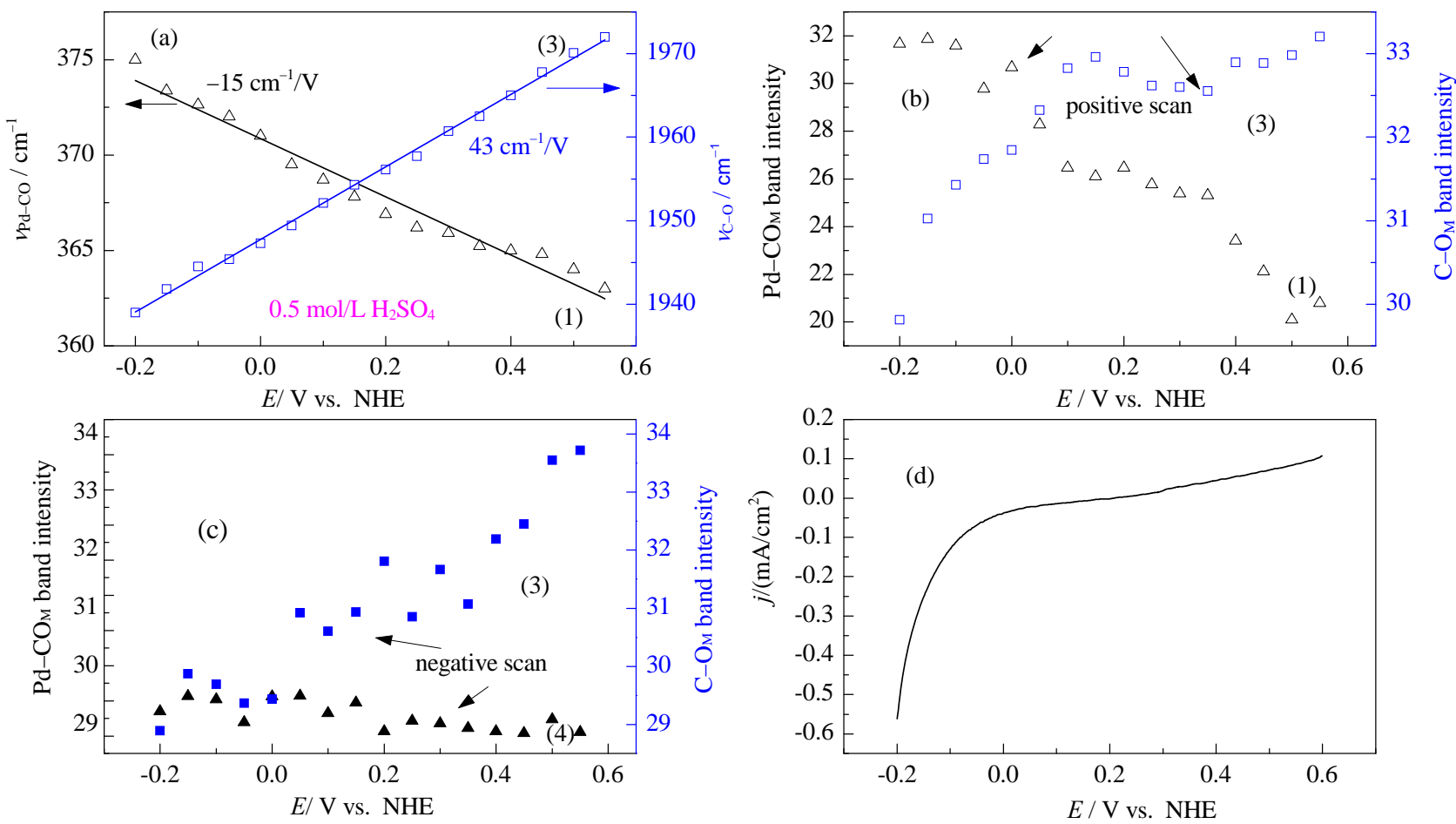

Fig. 5. Peak frequencies (a) and band intensities (b,c) of Pd-COM $(1,2)$ and $\mathrm{C}-\mathrm{O}_{\mathrm{M}}(3,4)$ from adsorbed $\mathrm{CO}$ on $55 \mathrm{~nm}$ Au@0.7 nm Pd/Pd as a function of electrode potential in $\mathrm{CO}$ saturated $0.5 \mathrm{~mol} / \mathrm{L} \mathrm{H}_{2} \mathrm{SO}_{4}$ during the positive-(b) and negative-going potential scan (c). (d) Cyclic voltammograms of $55 \mathrm{~nm}$ $\mathrm{Au} @ 0.7 \mathrm{~nm} \mathrm{Pd} / \mathrm{Pd}$ in $\mathrm{CO}$ saturated $0.5 \mathrm{~mol} / \mathrm{L} \mathrm{H}_{2} \mathrm{SO}_{4}$ solution during the positive-going potental scan. Scan rate, $1 \mathrm{mV} / \mathrm{s}$.

intensities is not clear; further studies on well-defined single-crystalline Pd are underway to clarify this.
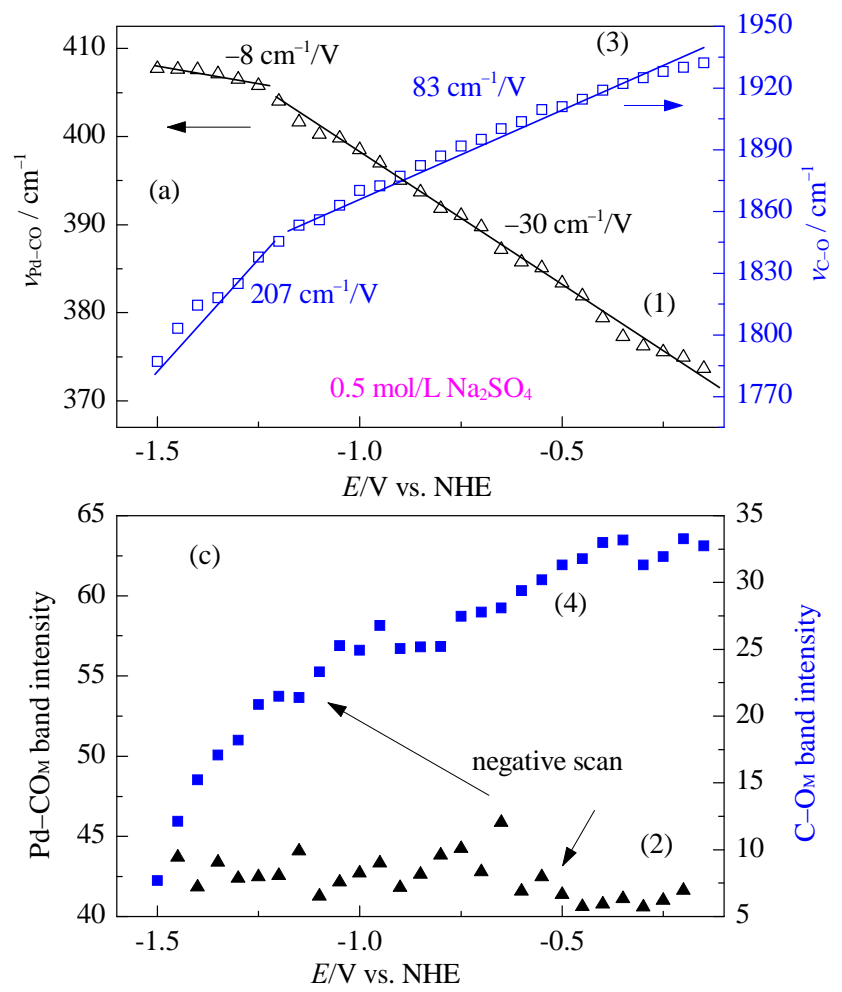

The values for $\mathrm{d} \nu_{\text {Pd-Com }} / \mathrm{d} E\left(-15 \mathrm{~cm}^{-1} / \mathrm{V}\right)$ and $\mathrm{d} v_{\mathrm{C}-\mathrm{om}} / \mathrm{d} E(43$ $\mathrm{cm}^{-1} / \mathrm{V}$ ) observed in $0.5 \mathrm{~mol} / \mathrm{L} \mathrm{H}_{2} \mathrm{SO}_{4}$ agreed well with values
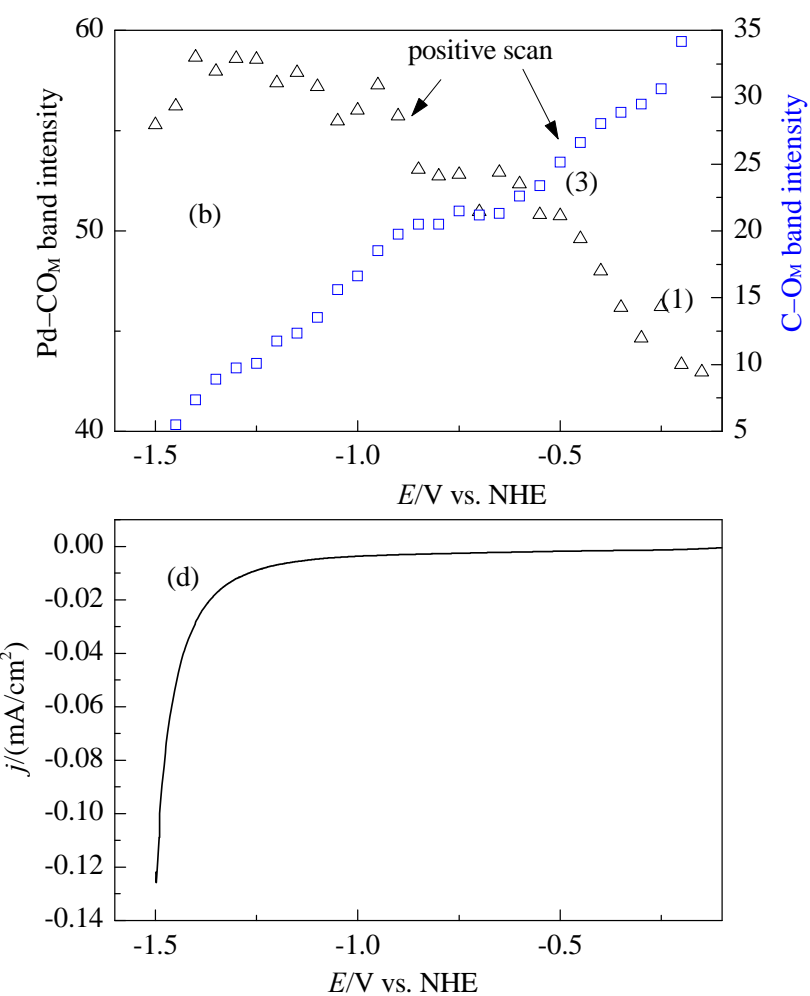

Fig. 6. Peak frequencies (a) and band intensities (b, c) of $\mathrm{Pd}-\mathrm{CO}_{\mathrm{M}}(1,2)$ and $\mathrm{C}-\mathrm{O}_{\mathrm{M}}(3,4)$ from adsorbed $\mathrm{CO}$ on $55 \mathrm{~nm} \mathrm{Au} @ 0.7 \mathrm{~nm} \mathrm{Pd} / \mathrm{Pd}$ as a function of electrode potential in $\mathrm{CO}$ saturated $0.5 \mathrm{~mol} / \mathrm{L} \mathrm{Na}_{2} \mathrm{SO}_{4}$ during the positive-(b) and negative-going potential scan (c). (d) Cyclic voltammograms of 55 $\mathrm{nm} \mathrm{Au@0.7} \mathrm{nm} \mathrm{Pd/Pd} \mathrm{in} \mathrm{CO} \mathrm{saturated} 0.5 \mathrm{~mol} / \mathrm{L} \mathrm{Na}_{2} \mathrm{SO}_{4}$ solution during the positive scanning. Scan rate $1 \mathrm{mV} / \mathrm{s}$. 

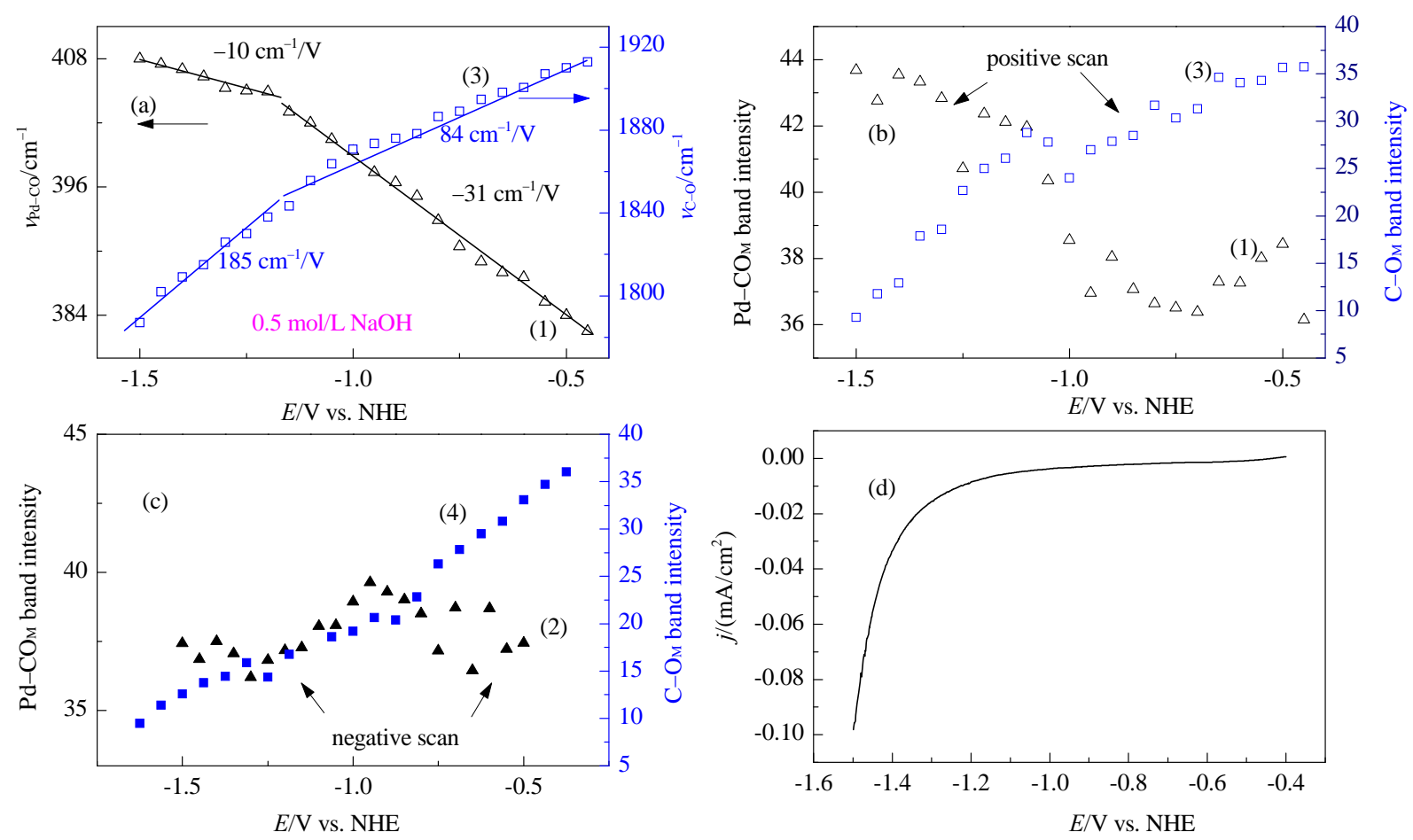

Fig. 7. Peak frequencies (a) and band intensities (b, c) of Pd-CO $(1,2)$ and $\mathrm{C}-\mathrm{O}_{\mathrm{M}}(3,4)$ adsorbed $\mathrm{CO}$ on $55 \mathrm{~nm}$ Au@0.7 nm Pd/Pd as a function of electrode potential in $\mathrm{CO}$ saturated $0.5 \mathrm{~mol} / \mathrm{L} \mathrm{NaOH}$ during the positive- (b) and negative-going potential scan (c). (d) Cyclic voltammograms of $55 \mathrm{~nm}$ $\mathrm{Au} @ 0.7 \mathrm{~nm} \mathrm{Pd} / \mathrm{Pd}$ in $\mathrm{CO}$ saturated $0.5 \mathrm{~mol} / \mathrm{L} \mathrm{NaOH}$ solution during the positive-going pote scan. Scan rate $1 \mathrm{mV} / \mathrm{s}$.

from previous reports measured under similar conditions [2]. However, the values of $83 \mathrm{~cm}^{-1}$ and $207 \mathrm{~cm}^{-1} / \mathrm{V}$ observed for $\mathrm{d} v_{\mathrm{C}-\mathrm{OM}} / \mathrm{d} E$ at more negative potentials in the CO-saturated 0.5 mol/L $\mathrm{Na}_{2} \mathrm{SO}_{4}$ solution were unusually high (Fig. 6(a)). Similar results were also observed for CO adsorbed at the Pd@Au nanoparticle film electrode in an alkaline solution (Fig. 7(a)), and such unusually high Stark slopes were found to be highly reproducible. Referring to the simultaneously recorded $i-E$ curve in CO-saturated $0.5 \mathrm{~mol} / \mathrm{L} \mathrm{Na}_{2} \mathrm{SO}_{4}$ (Fig. 6(d)), it was found that the abrupt changes in $\mathrm{d} v_{\mathrm{C}-\mathrm{OM}} / \mathrm{d} E$ and $\mathrm{d} \nu_{\mathrm{Pd}-\mathrm{COM}} / \mathrm{d} E$ occurred at the onset potential for the HER (ca. $-1.2 \mathrm{~V}$ ), which indicated that although the surface was saturated with $\mathrm{CO}$, dissociation of water to $\mathrm{H}_{\text {ad }}$ took place. In the present SERS study, we did not observe any band for $\mathrm{Pd}-\mathrm{H}$ vibrations at the atop site above

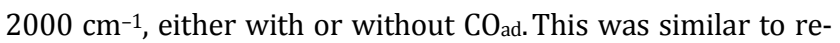
sults from a previous study published by Tian's group [35]. From such results, it was concluded that at negative potentials the adsorbed hydrogen atoms were located in bridge or hollow sites of the Pd surface, or inside bulk Pd.

\subsection{The origin of nonlinear Stark effects of $\mathrm{Pd}-\mathrm{CO}$ and $\mathrm{C}-\mathrm{O}$ stretching vibrations in neutral and alkaline solutions}

Several factors, such as (1) the effect of the double-layer electric field; (2) changes in $\mathrm{CO}_{\text {ad }}$ surface coverage; and (3) changes in the adlayer structures and adsorbate distribution might have contributed to the nonlinear potential-dependent peak frequencies of the $\mathrm{Pd}-\mathrm{CO}$ and $\mathrm{C}-\mathrm{O}$ stretching vibrations. We will discuss the effects of these factors one by one.

To clarify how the peak frequencies of the Pd-CO and C-O stretching vibrations changed with changes in the applied external electric field, we carried out DFT calculations using a slab model with four Pd layers. Some of us have previously made systematic investigations of the Pd-layer thickness-dependent CO adsorption, and the thickness-dependent electrocatalytic activity, using surface-enhanced Raman spectroscopy. It was found that the potential-dependent SERS behaviors of CO were rather similar with changes in the thickness of the Pd layer, except that there was a very small shift in the vibrational frequencies, compared with those observed for electrochemically roughened $\mathrm{Pd}$ electrodes (within $4 \mathrm{~cm}^{-1}$ for $\mathrm{C}-\mathrm{O}$ stretching vibrations, and $1 \mathrm{~cm}^{-1}$ for $\mathrm{Pd}-\mathrm{CO}$ stretching vibrations). Hence it is reasonable to calculate the potential-dependent frequency changes of the $\mathrm{Pd}-\mathrm{CO}$ and $\mathrm{C}-\mathrm{O}$ stretching vibrations using the 4-Pd-layer slab model. The calculated frequencies of the $\mathrm{Pd}-\mathrm{CO}_{\mathrm{B}, \mathrm{H}}$ and $\mathrm{C}-\mathrm{O}_{\mathrm{B}, \mathrm{H}}$ stretching vibrations were plotted as a function of the external electric field in the range from -1.0 to $0.5 \mathrm{~V} / \AA \AA$ (ca. -2.0 to $2.5 \mathrm{~V}$ vs. NHE, assuming that the thickness of the inner Helmholtz layer was $3 \AA$, and the potential of zero charge in the Pd-CO system was ca. $1 \mathrm{~V}$ vs. NHE [5]) (Fig. 8). The periodic DFT calculations in the potential region from ca. -2.5 to $2 \mathrm{~V}$ revealed that when the $\mathrm{CO}$ adsorption sites were fixed, the change in the electrode potential induced only a linear change in $v_{\mathrm{Pd}-\mathrm{CO}}$ and $v_{\mathrm{C}-0}$; this indicated that the nonlinearity of the Stark slopes observed using SERS could not be explained purely by the variation in the external electric field.

Each spectrum was measured over a period of $50 \mathrm{~s}$, and all of the experiments were performed under continuous flowing of a CO-saturated solution through the cell, and the spectra were thus recorded from the $\mathrm{CO}$ adlayer, which was well equil- 

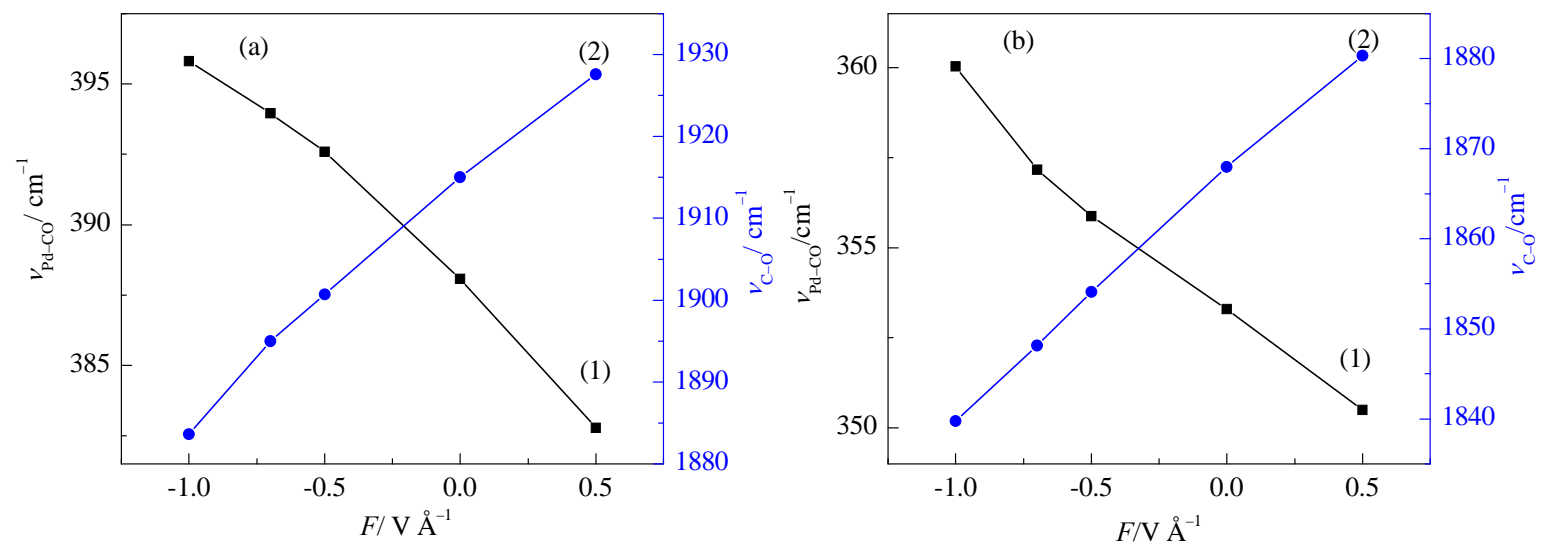

Fig. 8. Calculated electric field dependent peak frequencies of $\mathrm{Pd}-\mathrm{CO}_{M}(1)$ and $\mathrm{C}-\mathrm{O}_{\mathrm{M}}(2)$ based on a model with periodic slab structure of $\mathrm{CO}_{\mathrm{L}}+2 \mathrm{CO}_{\mathrm{B}}(\mathrm{a}$ and $\mathrm{CO}_{\mathrm{L}}+2 \mathrm{CO}_{\mathrm{H}}(\mathrm{b})$ based on density functional theory.

ibrated with the CO in the bulk solution. Several DFT calculations revealed that the $\mathrm{CO}$ binding energy increased when the electrode potential was shifted negatively into the potential region where the HER took place [1,7]; this led to slightly higher equilibrium $\mathrm{CO}_{\mathrm{ad}}$ coverages at negative potentials, compared with the coverages at positive potentials. Furthermore, recent DFT calculations showed that at $\mathrm{Pd} / \mathrm{Au}(111)$, both $\mathrm{H}$ and $\mathrm{CO}$ favor the three-fold hollow site adsorption configuration, and the adsorption energy for $\mathrm{H}$ is ca. $-0.6 \mathrm{eV}$, while that for $\mathrm{CO}$ is ca. $-1.8 \mathrm{eV}$ [36]. This indicates the induction of the desorption of $\mathrm{CO}_{\mathrm{ad}}$ by post-adsorbed $\mathrm{H}$ in the potential region when HER takes place is unlikely (however, adsorbed H-induced CO surface diffusion and re-distribution are possible, see discussion below). It should be mentioned that at $E<0 \mathrm{~V}$ in $0.5 \mathrm{~mol} / \mathrm{L}$ $\mathrm{H}_{2} \mathrm{SO}_{4}$ (and at $E<-1.0 \mathrm{~V}$ in the neutral and basic solution), slow reduction of $\mathrm{CO}$ might have taken place. In contrast, at $E>0.3 \mathrm{~V}$ in $0.5 \mathrm{~mol} / \mathrm{L} \mathrm{H}_{2} \mathrm{SO}_{4}$, slow oxidation of $\mathrm{CO}$ might have occurred, as evidenced by the small anodic current shown in Fig. 5(c). However, it was still unlikely that the variation in the $\mathrm{CO}_{\text {ad }} \mathrm{cov}$ erage was due to $\mathrm{CO}$ oxidation and reduction, because under the conditions of the present study, such processes were mainly kinetic-limited; i.e., if such processes occurred, the consumed CO should have been replenished easily by the adsorption of CO dissolved in bulk solution. Thus it was concluded that the spectral variation due to the change (decrease) in $\mathrm{CO}_{\mathrm{ad}}$ coverage, and coverage-induced changes in the dipole-dipole coupling interaction at different potentials, were negligible.

Based on the analysis above, the nonlinear Stark slopes observed in the present study for both $\mathrm{d} \nu_{\mathrm{c}-\mathrm{o}} / \mathrm{d} E$ and $\mathrm{d} \nu_{\mathrm{Pd}-\mathrm{Co}} / \mathrm{d} E$ were attributed to the changes in the CO adlayer structure. It has been confirmed using UHV studies that repulsion dominates the interaction among neighboring $\mathrm{H}$ and $\mathrm{CO}$ species co-adsorbed on transition metals. Recently, an infrared spectroscopic study on the adsorption of submonolayer CO at a Pt electrode revealed that in the potential region from 0.05 to 0.35 $\mathrm{V}$, post-adsorbed $\mathrm{H}$ atoms could force well-distributed $\mathrm{CO}$ to form islands on $\mathrm{Pt}$ [6]. Thus, a change in the $\mathrm{CO}_{\mathrm{ad}}$ adlayer structure can be envisaged when the potential is scanned from the HER potential region to a more positive region. In the HER potential region from -1.5 to $-1.2 \mathrm{~V}$, post-adsorbed $\mathrm{H}$ atoms formed by the dissociation of water might have forced the $\mathrm{CO}_{\mathrm{ad}}$ molecules previously adsorbed at the bridge sites to move to hollow sites. The more negative the electrode potential, the higher the coverage of $\mathrm{H}_{\mathrm{ad}}$ atoms, and the more $\mathrm{CO}_{\mathrm{B}}$ changed to $\mathrm{CO}_{\mathrm{H}}$. Since the $\mathrm{CO}_{\mathrm{M}}$ bands included stretching vibrations of both $\mathrm{CO}_{\mathrm{H}}$ and $\mathrm{CO}_{\mathrm{B}}$ (superimposed), the conversion of $\mathrm{CO}_{\mathrm{B}}$ to $\mathrm{CO}_{\mathrm{H}}$ toward negative potentials greatly decreased $v_{\mathrm{C}-\mathrm{OM}}$, and increased $\mathrm{d} \nu_{\mathrm{C}-\mathrm{OM}} / \mathrm{d} E$. In contrast, $\mathrm{d} \nu_{\mathrm{Pd}-\mathrm{COM}} / \mathrm{d} E \mid$ decreased in more negative potential regions, as a result of the offsetting effects from the decrease of $v_{\mathrm{Pd}-\mathrm{COM}}$ that was due to the site conversion $\left(\nu_{\mathrm{Pd}-\mathrm{COB}}\right.$ was higher than $\left.\nu_{\mathrm{Pd}-\mathrm{COH}}\right)$, and the increase of $\nu_{\mathrm{Pd}-\mathrm{COM}}$ that was due to the negative shift in the electrode potential, in well agreement with the present observations.

\subsection{The Stark effects of $P d-C O$ and $C-O$ stretching vibrations in acidic solution}

The abrupt changes in the Stark slopes of $\mathrm{C}-\mathrm{O}_{\mathrm{M}}$ and $\mathrm{Pd}-\mathrm{CO}_{\mathrm{M}}$ stretching vibrations that occurred in neutral and basic solutions were not observed in CO-saturated $0.5 \mathrm{~mol} / \mathrm{L} \mathrm{H}_{2} \mathrm{SO}_{4}$, when scanning the electrode potential from the HER region to the double layer region. In acidic solutions, the HER at a Pd electrode can be expressed using the following scheme [37]:

$$
\begin{gathered}
2 \mathrm{H}^{+}+2 \mathrm{e} \rightarrow 2 \mathrm{H}_{\mathrm{ad}} \\
2 \mathrm{H}_{\mathrm{ad}} \rightarrow \mathrm{H}_{2}
\end{gathered}
$$

In neutral and basic solutions, it goes through water dissociation as following

$$
\begin{gathered}
2 \mathrm{H}_{2} \mathrm{O}+2 \mathrm{e} \rightarrow 2 \mathrm{H}_{\mathrm{ad}}+2 \mathrm{OH}^{-} \\
2 \mathrm{H}_{\mathrm{ad}} \rightarrow \mathrm{H}_{2} \\
\mathrm{H}_{\mathrm{ad}}+\mathrm{H}_{2} \mathrm{O}+\mathrm{e} \rightarrow \mathrm{H}_{2}+\mathrm{OH}^{-}
\end{gathered}
$$

Because the absorption of hydrogen into a Pd electrode can occur more easily in an acidic solution, where the concentration of $\mathrm{H}_{3} \mathrm{O}^{+}$is much higher than in neutral or basic solutions, the abrupt changes in the Stark slopes observed for the $\mathrm{C}-\mathrm{O}_{\mathrm{M}}$ and $\mathrm{Pd}-\mathrm{CO}_{\mathrm{M}}$ stretching vibrations in neutral and basic solutions, but not in acidic solution, could not be attributed to the changes in the structure of the Pd surface layer due to the absorption of $\mathrm{H}$ atoms into the bulk of the Au@Pd nanoparticles. The lack of sharp changes in the Stark slopes for the $\mathrm{C}_{-} \mathrm{O}_{\mathrm{M}}$ and $\mathrm{Pd}-\mathrm{CO}_{\mathrm{M}}$ stretching vibrations in acidic solutions indicated that 
different sites at the Pd surface might have been involved in the HER in the acidic and basic solutions [38,39]. It remains unclear whether water molecules in the double layer to be dissociated might also have had some influence on the peak frequencies of the $\mathrm{CO}_{\mathrm{ad}}$ species; e.g., via tuning of the potential drop across the double layer.

It should be noted that there remains one phenomenon to be explained in the SERS behavior of CO adsorption at the $\mathrm{Au} @ \mathrm{Pd}$ electrode; in particular, the higher $\mathrm{d} \nu_{\mathrm{c}-\mathrm{OM}} / \mathrm{d} E$ and $\mathrm{d} v_{\mathrm{Pd}-\mathrm{COM}} / \mathrm{d} E$ in the potential region of $\sim-1.2$ to $-0.15 \mathrm{~V}$ in 0.5 $\mathrm{mol} / \mathrm{L} \mathrm{Na}_{2} \mathrm{SO}_{4}$ and $0.5 \mathrm{~mol} / \mathrm{L} \mathrm{NaOH}$, compared with that in the potential region of $\sim-0.2$ to $0.55 \mathrm{~V}$ in $0.5 \mathrm{~mol} / \mathrm{L} \mathrm{H}_{2} \mathrm{SO}_{4}$ must be associated with the changes in the $\mathrm{CO}$ adlayer structure. However, it cannot be explained simply by the continuous conversion of $\mathrm{CO}_{\mathrm{ad}}$ from bridge to hollow sites, because both the potential region and the $\mathrm{pH}$ value of the solution varied simultaneously. Further investigations are underway to clarify these issues.

\section{Conclusions}

In summary, unique potential-dependent SERS spectral behavior of $\mathrm{Pd}-\mathrm{CO}$ and $\mathrm{C}-\mathrm{O}$ stretching vibrations at $\mathrm{Au} @ \mathrm{Pd}$ nanoparticle electrodes was observed. Throughout the examined potential region (from $\sim-1.5$ to $0.55 \mathrm{~V}$ ), three distinct Stark slopes for both $\mathrm{Pd}-\mathrm{CO}$ and $\mathrm{C}-\mathrm{O}$ stretching vibrations were observed: $\mathrm{d} \nu_{\mathrm{C}-\mathrm{OM}} / \mathrm{d} E$ decreased from $\sim 185-207 \mathrm{~cm}^{-1} / \mathrm{V}(\sim-1.5$ to $-1.2 \mathrm{~V})$ to $\sim 83-84 \mathrm{~cm}^{-1} / \mathrm{V}(\sim-1.2$ to $-0.15 \mathrm{~V})$, and then to 43 $\mathrm{cm}^{-1} / \mathrm{V}(\sim-0.2$ to $0.55 \mathrm{~V})$, while $\mathrm{d} \nu_{\mathrm{Pd}-\mathrm{COM}} / \mathrm{d} E$ changed from $\sim-10$ to $-8 \mathrm{~cm}^{-1} / \mathrm{V}(\sim-1.5$ to $-1.2 \mathrm{~V})$ to $\sim-31$ to $-30 \mathrm{~cm}^{-1} / \mathrm{V}$ $(\sim-1.2$ to $-0.15 \mathrm{~V})$, and then to $-15 \mathrm{~cm}^{-1} / \mathrm{V}(\sim-0.2$ to $0.55 \mathrm{~V})$. The abrupt changes in the Stark slopes for both Pd-CO and C-O stretching vibrations occurred at $-1.2 \mathrm{~V}$ when scanning the electrode potential from the HER region to the double layer region. This was confirmed by the simultaneously recorded CVs. DFT simulations with a slab model revealed that the change in the electric field across the interface only led to linear Stark slopes in a broad potential regime from -2.5 to $2 \mathrm{~V}$. Therefore, the abrupt changes in the Stark slopes were attributed to the change in the $\mathrm{CO}$ adlayer structure, which corresponded to the site conversion between $\mathrm{CO}_{\mathrm{H}}$ and $\mathrm{CO}_{\mathrm{B}}$ trigged by the co-adsorption of hydrogen atoms.Finally, we believe that a systematic study of the vibrational spectroscopic behavior of $\mathrm{CO}_{\mathrm{ad}}$ will greatly improve understanding of both $\mathrm{CO}$ adsorption/desorption processes, and the kinetics of heterogeneous catalytic reactions involving $\mathrm{CO}_{\mathrm{ad}}$ as intermediates, spectators, or poisoning species, because $\mathrm{CO}$ is one of the most important molecules in heterogeneous catalytic reactions. We also hope that our present study will stimulate interest and further investigations in such topics.

\section{Graphical Abstract}

Chin. J. Catal., 2016, 37: 1156-1165 doi: 10.1016/S1872-2067(15)61106-8

\section{Nonlinear Stark effect observed for carbon monoxide chemisorbed on gold core/palladium shell nanoparticle film electrodes, using in situ surface-enhanced Raman spectroscopy}

Pu Zhang, Yi Wei, Jun Cai, Yan-Xia Chen*, Zhong-Qun Tian University of Science and Technology of China; Xiamen University

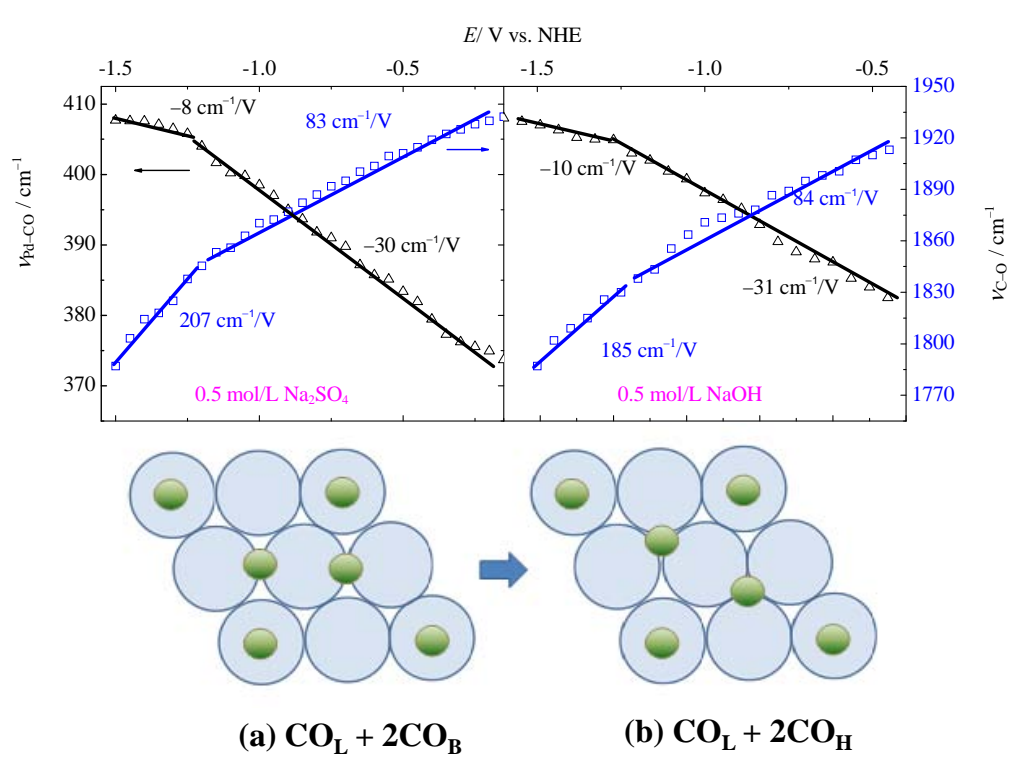

Abrupt changes in the Stark slopes for $\mathrm{CO}_{\mathrm{ad}}$ at Au@Pd-nanoparticle electrodes were observed using electrochemical in situ SERS. This phenomenon was explained by changes in the adsorption configuration of $\mathrm{CO}_{\text {ad }}$ induced by co-adsorbed hydrogen atoms in the HER region. 


\section{References}

[1] P. Deshlahra, E. E. Wolf, W. F. Schneider, J. Phys. Chem. A, 2009, 113, 4125-4133.

[2] S. Z. Zou, M. J. Weaver, J. Phys. Chem., 1996, 100, 4237-4242.

[3] V. Stamenkovic, K. C. Chou, G. A. Somorjai, P. N. Ross, N. M. Markovic, J. Phys. Chem. B, 2005, 109, 678-680.

[4] S. A. Wasileski, M. J. Weaver, Faraday Discuss., 2002, 121, 285-300.

[5] S. A. Wasileski, M. T. M. Koper, M. J. Weaver, J. Phys. Chem. B, 2001, 105, 3518-3530.

[6] Y. X. Chen, M. Heinen, Z. Jusys, R. J. Behm, J. Phys. Chem. C, 2007, $111,435-438$.

[7] D. C. Ferre, J. W. Niemantsverdriet, Electrochim. Acta, 2008, 53, 2897-2906.

[8] S. Z. Zou, R. Gomez, M. J. Weaver, Langmuir, 1998, 15, 2931-2939.

[9] M. J. Weaver, S. A. Wasileski, Langmuir, 2001, 17, 3039-3043.

[10] D. K. Lambert, Electrochim. Acta, 1996, 41, 623-630.

[11] P. Zhang, J. Cai, Y.-X. Chen, Z.-Q. Tang, D. Chen, J. Yang, D.-Y. Wu, B. Ren, Z.-Q. Tian, J. Phys. Chem. C, 2010,114, 403-411.

[12] K. Kunimatsu, J. Phys. Chem., 1984, 88, 2195-2200.

[13] M. J. Weaver, S. Z. Zou, C. Tang, J. Chem. Phys., 1999, 111, 368-381.

[14] G. Q. Lu, S. G. Sun, L. R. Cai, S. P. Chen, Z. W. Tian, K. K. Shiu, Langmuir, 2000, 16, 778-786.

[15] S. Pronkin, T. Wandlowski, Surf. Sci., 2004, 573, 109-127.

[16] B. N. J. Persson, R. Ryberg, Phys. Rev. B, 1989, 40, 10273.

[17] P. Zhang, Y. X. Chen, J. Cai, S. Z. Liang, J. F. Li, A. Wang, B. Ren, Z. Q. Tian, J. Phys. Chem. C, 2009, 113, 17518-17526.

[18] J. W. Hu, J. F. Li, B. Ren, D. Y. Wu, S. G. Sun, Z. Q. Tian, J. Phys. Chem. C, 2007, 111, 1105-1112.

[19] Z. Liu, Z. L. Yang, L. Cui, B. Ren, Z. Q. Tian, J. Phys. Chem. C, 2007,
111, 1770-1775.

[20] A. Czerwinski, J. Electroanal. Chem., 1994, 379, 487-493.

[21] B. Losiewicz, L. Birry, A. Lasia, J. Electroanal. Chem., 2007, 611, 26-34.

[22] G. Kresse, J. Hafner, Phys. Rev. B, 1993, 48, 13115-13118.

[23] G. Kresse, J. Hafner, Phys. Rev. B, 1993, 47, 558-561.

[24] G. Kresse, J. Furthmüller, Phys. Rev. B, 1996, 54, 11169-11186.

[25] J. P. Perdew, K. Burke, M. Ernzerhof, Phys. Rev. Lett., 1996, 77, 3865-3868.

[26] P. E. Blöchl, Phys. Rev. B, 1994, 50, 17953-17979.

[27] H. J. Monkhorst, J. D. Pack, Phys. Rev. B, 1976, 13, 5188-5192.

[28] M. Methfessel, A. T. Paxton, Phys. Rev. B, 1989, 40, 3616-3621.

[29] S. Z. Zou, R. Gomez, M. J. Weaver, J. Electroanal. Chem., 1999, 474, 155-166.

[30] V. V. Kaichev, I. P. Prosvirin, V. I. Bukhtiyarov, H. Unterhalt, G. Rupprechter, H. J. Freund, J. Phys. Chem. B, 2003, 107, 3522-3527.

[31] H. Unterhalt, G. Rupprechter, H. J. Freund, J. Phys. Chem. B, 2002, 106, 356-367.

[32] R. B. Jiang, W. Y. Guo, M. Li, D. L. Fu, H. H. Shan, J. Phys. Chem. C, 2009, 113, 4188-4197.

[33] P. J. Feibelman, Phys. Rev. B, 2001, 64, 125403-125408.

[34] M. Morkel, H. Unterhalt, T. Kluner, G. Rupprechter, H. J. Freund, Surf. Sci., 2005, 568, 146-156.

[35] Y. X. Jiang, J. F. Li, D. Y. Wu, Z. L. Yang, B. Ren, J. W. Hu, Y. L. Chow, Z. Q. Tian, Chem. Commun., 2007, 4608-4610.

[36] A. Roudgar, A. Gross, Chem. Phys. Lett., 2005, 409, 157-162.

[37] V. S. Bagotsky, Fundamentals of Electrochemistry, John Wiley \& Sons, Hoboken, 2005, 323-324.

[38] J. Zheng, Z. B. Zhuang, B. J. Xu, Y. S. Yan, W. C. Sheng, Sci. Adv., 2016, 2, e1501602.

[39] S. A. Wasileski, M. J. Weaver, M. T. M. Koper, Electroanal. Chem., 2001, 500, 344-355.

\title{
电化学原位表面增强拉曼光谱研究Au@Pd 纳米粒子薄膜电极上 吸附 CO 的斯塔克效应
}

\author{
张 普, 卫 怡 ${ }^{\mathrm{a}}$, 蔡 俊 ${ }^{\mathrm{a}}$, 陈艳霞, ${ }^{\mathrm{a},}$, 田中群 ${ }^{\mathrm{b}}$ \\ a中国科学技术大学化学物理系, 合肥微尺度国家实验室分子原子研究部, 安徽合肥230026 \\ b厦门大学化学化工学院化学系, 固体表面物理化学国家重点实验室, 福建厦门361005
}

摘要: 电化学 Stark 效应是指电极溶液界面的吸附物或金属-吸附物之间的化学键的振动频率随电极电势而发生变化的现 象. 研究该效应, 可以更好地理解吸附物与基底的相互作用 (如吸附构型、吸附取向和覆盖度等随电位的变化), 也可反过来 推断电极基底的电子构型及其随电势的变化规律, 对理解电化学双电层的结构以及电催化反应的构效关系都很有帮助. 多年以来, 电极表面吸附 CO 的电化学 Stark 效应广受关注, 是由于 CO 为很多小分子氧化的中间产物, 研究 CO 的谱学行 为, 可加深对 CO 以及其它能产生 CO 中间物有机小分子的电催化氧化机理和动力学的理解; 另一方面, CO 与过渡金属之 间普遍存在 $\sigma$ 给电子以及 $\pi$ 反馈电子作用, 因此 $\mathrm{CO}$ 也可作为探针分子, 通过考察 $\mathrm{CO}_{\mathrm{ad}}$ 以及 $\mathrm{M}-\mathrm{CO}_{\mathrm{ad}}$ 的振动频率的变化, 可 推断相应条件下基底的电子与几何结构等信息.

本文使用电化学原位表面增强拉曼技术, 在一个大的电势范围内考察了 Au@Pd 纳米粒子薄膜电极上饱和吸附 CO 的 振动光谱行为, 以期更好地理解 $\mathrm{CO}_{\mathrm{ad}}$ 与基底的成键作用与电极电势之间的关系. 由于纯 $\mathrm{Pd}$ 电极表面的拉曼信号太弱, 实 验使用具有核壳结构的 Au@Pd 纳米粒子薄膜作为模型电极, 并利用 $\mathrm{Au}$ 核的拉曼增强特性. 宽广的电势范围约-1.5 到 $0.55 \mathrm{~V}$ vs. NHE, 通过使用酸性、中性以及碱性电解质得以实现. 实验考察的电势上限由 $\mathrm{CO}_{\mathrm{ad}}$ 氧化起始电位决定, 而下限由 强烈氢析干扰测量所限制. 结果表明, 在检测的电势范围内, $\mathrm{C}-\mathrm{O}_{\mathrm{M}}(\mathrm{M}$ 指在电极表面的桥式吸附 $\mathrm{CO}$ 和穴位吸附 $\mathrm{CO}$ 所形成 的谱带重叠) 和 $\mathrm{Pd}-\mathrm{CO}_{\mathrm{M}}$ 键的振动频率可以分为三段: $\mathrm{d} v_{\mathrm{C}-\mathrm{OM}} / \mathrm{d} E$ 在 $-1.5 \sim-1.2 \mathrm{~V}$ 范围内是 $185 \sim 207 \mathrm{~cm}^{-1} / \mathrm{V}$, 在 $-1.2 \sim$ $-0.15 \mathrm{~V}$ 是 $83 \sim 84 \mathrm{~cm}^{-1} / \mathrm{V}$, 在 $-0.2 \sim 0.55 \mathrm{~V}$ 是 $43 \mathrm{~cm}^{-1} / \mathrm{V}$; 而 $\mathrm{d} v_{\mathrm{Pd}-\mathrm{COM}} / \mathrm{d} E$ 在 $-1.5 \sim-1.2 \mathrm{~V}$ 范围内是 $-10 \sim-8 \mathrm{~cm}^{-1} / \mathrm{V}$, 在 $-1.2 \sim$ $-0.15 \mathrm{~V}$ 是 $-31 \sim-30 \mathrm{~cm}^{-1} / \mathrm{V}$, 在 $-0.2 \sim 0.55 \mathrm{~V}$ 是 $-15 \mathrm{~cm}^{-1} / \mathrm{V}$. 与同时记录的极化曲线对比, 认为在中性和碱性介质中所观察 
到 $\mathrm{d} v_{\mathrm{C}-\mathrm{OM}} / \mathrm{d} E$ 在 $-1.2 \mathrm{~V}$ 附近的急剧变化与电极表面发生了强烈的析氢反应有关. 另外, 结合密度泛函理论模型计算, 认为 共吸附的 $\mathrm{H}$ 减少了 $\mathrm{CO}_{\mathrm{ad}}$ 从桥式构型到穴位构型的转变, 在酸性介质中这种变化不明显, 可能是由于对应的电势较高, 桥式 吸附的 CO 比例越大, 桥式向穴位的转变本身相对较少.

关键词: 一氧化碳; 表面增强拉曼光谱; 钯; 密度泛函理论; 斯塔克效应

收稿日期: 2016-03-14. 接受日期: 2016-04-14. 出版日期: 2016-07-05.

*通讯联系人. 电话/传真: (0551)63600035; 电子信箱: yachen@ustc.edu.cn

基金来源：国家自然科学基金(21473175); 国家重大科学仪器设备开发专项(2011YQ03012416); 国家重点基础研究发展计划(973 计划, 2015CB932301).

本文的英文电子版由Elsevier出版社在ScienceDirect上出版(http://www.sciencedirect.com/science/journal/18722067). 